\title{
Waste and the neoliberal work of blame: Reading politics from Cape Town's informal landscapes
}

I rifiuti e il meccanismo neoliberale del biasimo. Un'analisi politica dai paesaggi informali di Cape Town

\section{Angela D. Storey}

\section{OpenEdition}

\section{Journals}

Electronic version

URL: http://journals.openedition.org/aam/3311

DOI: 10.4000/aam.3311

ISSN: 2038-3215

Publisher

Dipartimento Culture e Società - Università di Palermo

Electronic reference

Angela D. Storey, "Waste and the neoliberal work of blame: Reading politics from Cape Town's

informal landscapes", Archivio antropologico mediterraneo [Online], Anno XXIII, n. 22 (2) | 2020, Online since 31 December 2020, connection on 01 February 2021. URL: http://journals.openedition.org/aam/ 3311 ; DOI: https://doi.org/10.4000/aam.3311

This text was automatically generated on 1 February 2021.

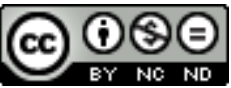

Archivio antropologico mediterraneo è distribuita con Licenza Creative Commons Attribuzione - Non commerciale - Non opere derivate 4.0 Internazionale. 


\title{
Waste and the neoliberal work of blame: Reading politics from Cape Town's informal landscapes
}

\author{
I rifiuti e il meccanismo neoliberale del biasimo. Un'analisi politica dai paesaggi \\ informali di Cape Town
}

Angela D. Storey

\section{Introduction}

1 In January 2015, the City of Cape Town posted on Twitter a photo of then-Mayor Patricia de Lille at the launch of a public service campaign targeting open dumping and the disposal of garbage into the sewer system. The mayor was shown pasting a poster from the Illegal Dumping Campaign onto a wall in the middle of a Cape Town community. The poster read «Every time you throw disposable diapers down the toilet, you make people sick», under an equation in icon form: diaper plus toilet equals person in hospital bed (CCT 2015b) (Picture 1)1.

2 The mayor's speech at the launch noted the cost of what she called "illegal dumping" and the importance of educating residents:

[...] the City spends approximately R350 million ${ }^{2}$ annually to clear waste from open spaces, sewer systems and toilets. [...] The Illegal Dumping campaign will create awareness about the damaging effects of illegal dumping and educate residents on the costs of clearing waste and on how to dispose of waste in the correct way. [...] At present, incidents of illegal dumping are under-reported, and communities are encouraged to work with us to ensure that more incidents are reported. We urge communities to take down the details of perpetrators and their vehicles, including registration numbers and, if possible, gather photographic evidence so that we can prosecute those who dump illegally (City of Cape Town 2015a).

3 The campaign framed urban residents as responsible to care for waste and infrastructure, emphasizing a particular understanding of responsible behaviors 
including "correct" use of services, disposal of waste, and reporting of violators. The poster presented a seemingly straightforward equation of this type of material care: your waste plus misuse of infrastructure equals your health problem. This interpretation of responsibility reflects the adoption by the City of Cape Town (CCT) and other South African municipalities of neoliberal policies, ideologies, and technologies that individualize access to and struggles for basic services (Dawson 2010; James 2013; von Schnitzler 2016). The campaign pushed this individualistic approach further, eliding discourses of responsibility and illegality to create a politics of blame (Heyman, Smart 1999; Ferradás 2013).

4 While the campaign ostensibly addressed all city residents, it emphasized through language, action, and context a focus on residents of the city's several hundred informal settlements - shack communities on squatted sites with limited access to waste management and other basic services, including electricity and water. Clogged toilets and open dumping sites were also significant concerns for residents of informal settlements, but were understood through a starkly different lens than that presented in the mayor's poster.

5 Against the city's neoliberal approach to responsibility sat a politicized, community understanding of actions and objects, one that emphasized the inadequacy of service delivery and its impacts on everyday life. The work of local activist organizations (Miraftab, Wills 2005; SJC 2013; Storey 2014) and resident narratives of everyday life highlight this approach. In interviews conducted with residents of informal areas in Khayelitsha, a suburb located in the margins of Cape Town, residents repeatedly voiced their daily actions as unavoidable practices resulting from inadequate service provision. Residents emphasized the impacts of limited services upon daily regimes of care for self, infrastructure, and community. Service limitations, the city's inadequate attention to maintenance, and the absence of long-term plans for informal area upgrading forced communities to provide for their own needs. Here, representatives of the city government who had not fulfilled post-apartheid promises of full services and housing were those seen as negligent. The landscape of informality was markedly understood as highly politicized, defined by the impacts on everyday life of historically deep differentials of power (Simone 2004; Pieterse 2008).

6 This article argues that neoliberal framings of responsibility produce a moral-legal discourse of blame that actively erases both structural inequality and the politics of everyday material life at urban peripheries. I make this argument in two sections: first, I explore scholarship on neoliberal governance and infrastructure in order to frame the claims of citizen responsibility presented in the Illegal Dumping Campaign. Second, I discuss a competing understanding of responsibility that emerged from ethnographic work with residents of informal settlements. Here, residents framed the city as negligent and presented an overtly political and structural reading of material life. Read alongside each other, these two logics demonstrate that the neoliberal work of blame can be seen as a delinking of the political and material context of marginalized urban experience.

7 The ethnographic data in this article is based upon 22 months of fieldwork in Cape Town conducted over the course of a decade (2010-2019). Specifically, I focus on the experiences of one specific informal settlement located in Khayelitsha, drawing from a series of 34 in-depth, semi-structured interviews conducted with residents of this site in 2013 and $2014 .^{3}$ I present vignettes from the experiences of three residents that 
reflect many struggles of this community and others like it. Interviews are contextualized by participant observation conducted within public spaces, inside homes, at community events, and within the offices and meeting spaces of residents, as well as follow-up interviews with key informants in 2015, 2017, and 2019. This data is part of a wider project that includes interviews and participant observation conducted with more than 150 residents of multiple informal settlements and with social movements and community-based organizations struggling to expand access to basic services in Cape Town.

8 The ethnographic data in this article provides a response to the city's Illegal Dumping Campaign, not by exploring the reaction of residents, but by re-situating the campaign's claims within residents' everyday lives and their complex interactions with waste and waste management. Highlighting lived experiences serves to juxtapose the campaign's simplified neoliberal logic against the everyday and highly politicized interactions with waste located within their targeted communities. This is a clash not only of logics of responsibility but also of visions of the future. As the campaign presents a future of re-shaped individual action, residents posit a future of structural change - a result of their capacity to imagine and work for a different future, a capacity built through collective action (Appadurai 2004).

Peripheral spaces are often seen as the urban "otherwise": the undeveloped set against the developed, the unmade against the made, and the informal against the formal (Simone 2004). I build upon work that acknowledges the complex lived realities and political engagements of South African urban residents, highlighting the production in peripheral spaces of new and multiple relations to governance and justice (oldfield, Stokke 2007; Pieterse 2008; Robins et al 2008; Oldfield, Greyling 2015). Reading neoliberal projects not only against their specific reception but also against everyday life highlights the inescapable politics of material experience in the city's margins.

\section{Infrastructural Citizenship Post-apartheid}

10 The restructuring of municipal resource distribution under neoliberal modes of governance has drawn significant academic attention (Galvin, Habib 2003; McDonald, Ruiters 2005; von Schnitzler 2016). Prompting marked structural changes in the delivery of services via processes of commercialization, commodification, and privatization, neoliberal policy also necessitates an ideological transition from seeing resources such as water as public goods to defining them as commodities (Kaika, Swyngedouw 2000; Bakker 2003). Such shifts obligate not only continual marketgovernment interaction, but also the re-creation of citizen-government relationships on the model of customer-market (Mosse 2008; von Schnitzler 2016).

11 South Africa's ready adoption of neoliberal policies and practices post-apartheid includes significant shifts in national and municipal delivery of basic services for water, sanitation, and electricity (Galvin, Habib 2003; McDonald, Ruiters 2005; Robins 2014a; Chance 2015). The creation of new relations of governance can be seen starkly, with citizens taught through public education and technological interventions such as prepaid water and electricity meters to become customers and to treat public resources as commodities, individualizing struggles for resources (Harvey 2005; von Schnitzler 2008; Dawson 2010). Campaigns promoting prepaid metering have made this link by «arguing that national reconstruction was only possible if each individual citizen 
realized that while liberation had provided them with rights, it had also imposed duties on them» (von Schnitzler 2008: 907). The unbundling of public infrastructural provision produces what Graham and Marvin call "splintering urbanism" (2001) - the demise of an infrastructural ideal premised on standardized, national access and a concomitant disintegration of urban socialities.

Such practices reflect not only broad neoliberal rationale but also the historical and social context of their implementation. In South Africa, neoliberal policies have responded to - and sought to co-opt - socio-political currents, drawing upon a rhetoric of democratic choice and responsibility. During the implementation of pre-paid water metering in Soweto, for example, signage attempted to link meters to the landmark constitutional right to water by re-naming them "freepay meters" (Dawson 2010). Likewise, a waste management program in Cape Town in the early 2000s drew upon ideas of participatory democracy and empowerment to justify low-wage and unpaid labor (Miraftab 2004). Here democratic logics were reframed to emphasize individual action, erasing on-going struggles for services and ignoring the history of collective action against apartheid which focused upon garnering both political and material inclusion in the state (von Schnitzler 2008; Hart 2008). The post-apartheid citizen thus becomes subject to their own duties and choices, with the language and ideology of responsibility replacing that of rights (James 2013).

The Illegal Dumping Campaign similarly posits that responsibility is the task of citizens in relation to infrastructural systems and basic services. While the campaign was meant to reshape residents' daily actions, representations of residents or of their daily actions were woefully absent. In the poster pasted up by the mayor, both waste and infrastructure hung in empty space: isolated objects devoid of their trappings of use, location, or any context for them becoming "irresponsibly" mixed. The residents of targeted areas only appeared in the final image of the icon trio (diaper + toilet = person in hospital bed): as those suffering illness. Their own, presumably causal actions were meant to be understood by the viewer without being displayed. Indeed, the actions and selves of informal settlement residents were implicitly tied to the spaces they inhabit, the landscapes of informality already marked in the South African popular imagination - and globally - by poor hygiene, dis-repair, and improper uses of infrastructure (Robins 2014b; Desai et al 2015; McFarlane, Silver 2017). The posters depend upon such existing ideas about informality and the worthiness of certain modes of material practice. Actions were understood in the abstract, within the poster's floating void of clean diapers and pristine toilet bowls. Here objects, actions, and people were decontextualized, ungrounded, left in empty space.

The Illegal Dumping Campaign is not the only space in which a depoliticized and decontextualized understanding of responsibility for services has been assigned to informal settlement residents. For example, in 2013, a local advocacy organization invited city staff to speak at an event following a community audit of sanitation (SJC 2013). The city's Executive Director for Utility Services told assembled residents that the community should be involved in governance insomuch that residents «take responsibility for the infrastructure they use», including proper usage and the reporting of violators, but widely ignored calls for service improvement (Storey 2014). This emphasis on depoliticized responsibility extends to the Provincial level, with an isiXhosa language ${ }^{4}$ billboard posted by the Western Cape Government adjacent to informal settlements in 2015 reading: $« 99.1 \%$ of us now have access to running water. 
Let's look after our services, for a better future» ${ }^{5}$. While pitched to a general audience, the call appeared to target nearby communities with shared, publicly-maintained - and still very limited - services.

The impacts of framing "improper" action were very real, as the existence of dumping sites and clogged toilets could be key rationale by which the city denied further services. Residents, seemingly through their own actions, were framed as unsanitary subjects, distanced by their "improper" regimes of self-care from the material promises of citizenship (Briggs 2004). The city's discourse of responsibility relied upon a certain understanding of daily lives within informality - and relationships to infrastructure in order to rationalize service limitations. At the campaign launch Mayor De Lille stated, «The R350 million we spend annually to clear illegal waste could be much better spent elsewhere on new services and infrastructure. For example, the City could have built 2,065 houses, or provided electricity for 31,627 homes» (CCT 2015a). These statements mirror the logic of the poster: your actions are the cause of your continued suffering. Be responsible and you could, instead, have electricity or a house.

The campaign went a step further, equating the actions of individuals not only with their own suffering and absent services, but also as the reason for limited services benefitting the entire area. In three other images created by the campaign a pile of rubble was equated to a library, a playground, and a hospital, each with the tagline: «Dumping illegally wastes resources that could be used elsewhere» (CCT 2015c) (Picture 2). There is no subtlety to the message: inadequate services were the result of residents' own actions.

These approaches to responsibility fit interestingly alongside post-apartheid adoption of redistributive practices, such as direct grants, that enroll citizens in starkly different relations to the state, suggesting neoliberalism is not monolithic (Ferguson, Gupta 2002; Ferguson 2009, 2015). Indeed, for CCT, the overlapping of neoliberal policies with those that emphasize poverty alleviation and basic service access (Jaglin 2008) offers a critical site for understanding how ideologies of neoliberalism travel, adapt, and reproduce. The particularities of South African history provide an important context for understanding both the framing of neoliberal practices by government actors and the impacts - and interpretation - of these practices by communities (Hart 2013).

\section{The Informal Everyday}

18 Khayelitsha sits in the eastern margins of Cape Town. Founded and constructed in the 1980s to house black workers at a distance from the white city center (Cook 1992), today Khayelitsha exists as a patchwork of residential areas: neighborhoods of bankfinanced houses, areas of government-built houses, and sections of informal settlements - shacks squatting on a mix of public and private lands. The 2011 South African Census placed Khayelitsha's total residency at nearly 400,000 , with $54.5 \%$ of the population living in informal housing (CCT 2013); other estimates of the population are significantly higher (SJC 2013). While some informal dwellings are in the backyards of formal houses, the majority exist in informal settlements - dense expanses of tinroofed shacks (CCT 2013). Khayelitsha is not the only area of Cape Town with informal settlements: $22 \%$ of the entire city's households stay in informal dwelling (CCT 2012). The post-apartheid population of Khayelitsha remains overwhelmingly Black $-98.6 \%$ of residents identified as Black African in the last census (CCT 2013). 

such as site ownership, environmental conditions, and length of tenure. Water provision is most common via shared taps positioned in common spaces, with the city's goal set at no more than 25 households sharing a single tap (CCT 2020). Electricity is provided by the parastatal Eskom via pre-paid meters, although not all sites qualified. Sanitation provision - including waste pick-up, provision of toilets, and accessibility of drains - varies widely. Drains are sometimes next to toilet blocks but often are only available as storm water drains along paved roads at the edges of informal areas. Waste management can include provision of garbage bags, trashcans, dumpsters, and pick-up services, with access varying. Toilet provision ranges from nothing at all to shared fullflush toilets, and, between these extremes, three forms of temporary toilets. The city's goal for sanitation provision to informal settlements is set at one toilet per five households (CCT 2020), with most sanitation shared. Khayelitsha's informal settlement residents are what Appadurai calls «citizens without a city» (2002: 26) - pushed into poor conditions in peripheral spaces, working in marginal and low-wage work, and underserved by city infrastructures.

Zanele $^{6}$ is one of the older informal settlements in Khayelitsha. With the initial shacks built before Mandela's election in 1994, residents said their community was «older than freedom». Between 2013 and 2015, Zanele remained largely disconnected from formal municipal services, supposedly as a result of the site's built environment and winter floods. The several hundred shacks shared about a dozen water taps; drains existed only along bordering roads. Just a few chemical toilets were provided to a daycare and the nearest garbage collection point was in an adjacent site - but locked on nights and weekends. Zanele had no roads through it, only small winding paths that jogged around the edge of each home, making the dense site nearly impossible to navigate in a linear fashion. Limited open space and lack of roads were reasons noted by the city to residents for the nearly wholesale absence of sanitation.

21 An outspoken amaXhosa woman, Noluvo had been a resident of Zanele for 13 years, when I interviewed her in 2013. In her upper-30s, Noluvo lived with her three children, the youngest a toddler and the oldest a teenager. She settled in Zanele because an uncle lived in a formal house nearby. Absent sanitation provision, Noluvo and her children used her uncle's flush toilet; on weekends she was obligated to clean the bathroom as payment for use. Noluvo's experience echoes widespread and long-term patterns of reliance upon kinship relations and social ties to access services within Cape Town's peripheral spaces (Besteman 2008; Ross 2010; Makhulu 2015). Indeed, Noluvo's experience mirrored that of 33 other residents I interviewed in Zanele, as well as more than one hundred residents of other informal settlements throughout Khayelitsha. Most residents shared similar stories of their struggles to access services, reliance upon kin and community, and frustration with inadequate services.

Noluvo was employed as a domestic worker, taking a series of buses and shared taxis into the city center to clean houses. Before leaving early each morning, she emptied the bucket that her family used at night as a toilet. During the day they walked several minutes to use her uncle's flush toilet, but at night a fear of crime made the walk too risky. In Zanele, as in other informal areas, residents often reported being mugged, attacked, and raped when walking to toilets, especially at night (Ndifuna Ukwazi 2014). Noluvo and her children urinated into a bucket at night and defecated into newspapers inside a plastic bag. In the morning, the waste was dumped into a storm drain. If the

Archivio antropologico mediterraneo, Anno XXIII, n. 22 (2) | 2020 
drain was blocked, as occurred often, waste was dumped into the "dirty place," also called the nyu-nyu, an open area in the center of the community where many dumped general household waste and human waste. This area was a small wetland, a sandy depression that flooded in the winter and grew tall reeds in the summer. It was also the only open space in this otherwise extremely dense site. In interviews with Zanele residents about their modes of service access and everyday usages, when I asked where their household disposed of waste, many would respond: «I dump it in that dirty place». Residents met resource needs through a constellation of extended and self-made infrastructures, often relying upon the land: emptying waste in open spaces, building sinks for waste water, and using the sand substrate to bury electricity lines. Absent tenure, and unsure if city promises for formal housing would ever be fulfilled, their situation as long-term squatters could be felt daily in interactions with informal infrastructures and the physical space of their communities. Decisive and vocal, Noluvo had been elected a leader in a local group that focused on garnering infrastructural and housing improvements. While their advocacy resulted in the construction of a small number of infrastructural improvements in the years following our 2013 interview - a few new taps, and a small number of shared, flush toilets - they were required to labor daily to maintain tenuous lines of connection to many needed infrastructures still accessed largely through informal and illegal connections. In our conversations, Noluvo framed the necessity of dumping waste into the nyu-nyu and of using her uncle's toilet as structural failures of the post-apartheid era, mirroring discontent across South Africa (Hart 2008). Although her daily work to manage waste was largely completed at a household level, Noluvo saw the struggle for resources as a collective endeavor. In addition to advocacy, Noluvo and many Zanele residents shared labor to expand informal infrastructures, including collective work to manage flooding, fix electricity cables, and provide services to communal spaces like the daycare. While never sufficient and always frustrating, these labors were attempts to make life possible.

The language of service delivery reflects the complex socio-political situation of infrastructure post-apartheid. While the city's posters framed dumping as "illegal" to articulate a moral-juridical judgment, residents also spoke about various modes of infrastructural access as illegal. The use of the term within communities, however, was meant to overtly highlight their exclusion from formal services, naming the processes of abjection that prevented their entry into modern infrastructural worlds (Anand 2012; Robins 2014a). The term, then, became a marker of exclusion emblematic of competing logics: one individual and the other structural. As Ferradás (2013) notes, the production of illegalities draws upon and compounds existing modes of exclusion, working at times to transform the marginal into the illegal. Illegalization - the «sociopolitical process that serves to uphold particular relations of power and delegitimize others» (Thomas, Galemba 2013: 211) - draws on moral-legal discourses to produce new subject relations to the state and politics of blame (Heyman, Smart 1999; Ferradás 2013; Heyman 2013). Residents in Zanele actively sought to invert the process of illegalization surrounding their actions, taking language meant to exclude and criminalize their actions and employing it as an overtly politicized marker of their structural exclusion.

In Zanele I often spent time in the home of Tata Bonani, a community leader who lived near the nyu-nyu and who spoke emphatically of their necessary use of illegal services. Whenever we spoke about the extended electricity connections or water pipes, or the 
informal dumps, he would emphatically say «we must» - we must have electricity, we must have water, we must have sanitation. If the city won't provide, «we must». Bonani spoke openly and clearly about the services in and around his shack as illegal. The term appeared often in his discussions at home and in his work with social movements and development groups, punctuating his conversations as they traversed fluently between English and Xhosa. A middle-aged and serious amaXhosa man, Bonani would grimace and purse his lips when we spoke about the nyu-nyu. Sitting in his small living room, he would wave his hand dismissively towards the open door, the nyu-nyu only a few meters beyond the opening, and talk about summer smells and winter floods. Over the sound of the radio on his cell phone tuned to local news, Bonani outlined their letters to the city, protests on the highway, and pleas to politicians - all attempts to garner full, legal access to services. Proximity to the nyu-nyu and its waste highlighted for Bonani the extent to which the city was to blame for Zanele's absent services: each bucket of waste dumped on the site indicated the invisibility and insignificance of their struggles.

The nyu-nyu was a site of risk and concern, but also a critical space used in the absence of services. In a community with no provision of waste containers, erratic garbage pickup, and few open plots, the concentration of waste in one area was a collective action in isolating it. Young children defecated in the nyu-nyu because the other proximate option was using a bucket, which would be dumped there or in a drain. The few nearby drains were heavily used for waste and often became blocked. Despite a lack of alternative disposal sites, residents were chastised by city employees for the regular need to unclog drains. In the absence of formal, frequent waste removal, the creation of a dumping site was one of the few available choices.

A politicized understanding of the nyu-nyu, which justified its necessity in the absence of formal services, did not mean residents enjoyed having a dump near their homes. Indeed, bodily relationships to waste necessitated by service exclusion were shaped by tensions between a politics of disgust and one of dignity (Desai et al 2015). In interviews, residents moved seamlessly between comments about dumping waste in the nyu-nyu, decrying its existence, and a frustration with the lack of alternatives. Thenjiwe, a Xhosa woman in her 30s who had lived in Zanele for 14 years, said that at night she and her husband utilized a bucket inside their shack for toilet needs. During the day, she walked 20 minutes to use flush toilets in another settlement. Thenjiwe lived in a lowlying area and her family had been flooded out of their shack the winter before, water seeping up through the sand underneath the carpet. In previous years they had lost their shack to fire, flames spreading quickly in the dense site. She says of the risks, «If it's not water, it's fire». In 2013 her children went to stay with family in anticipation of flooding. Despite being promised relocation by a city representative, nothing had happened for nearly a year; "we've just been waiting, waiting, waiting, but no one ever comes to us", she said. As the winter rains began, the nyu-nyu was the first to flood, recirculating waste into the homes from which it came.

With persistent discontent over service delivery, and despite steadily decreasing feelings of the ability to influence practices of governance (Thompson 2014), informal settlement residents persist in activism and in framing everyday actions as politicized. These paired actions challenge external valuations of individual responsibility. For Noluvo, Bonani, Thenjiwe, and other Zanele residents, their everyday life was inescapably political; their relations to decision-makers and structures of governance 
reflected in activism and everyday life. The politics of Cape Town's peripheral spaces highlight such multiple and contested relations to the state and city. Beyond being the target of activism, structures of governance can also be objects of engagement (Oldfield, Stokke 2007), co-producers of political discourse (Thorn, Oldfield 2011), understood through clientelistic relations (Robins et al 2008), or addressed concurrently through competing modes of political action (Robins 2014b; Macfarlane, Silver 2017). Around these relations of civil and political society, contestation extends into everyday life. Attending to mundane material work, like the management of waste, grounds postcolonial scholarship within the everyday of urban life in the Global South (Simone 2004; Mbembe, Nuttall 2004; Pieterse 2008).

Narratives from Zanele residents show the inextricable links between activism and the materiality of life in informal settlements. For residents of Zanele, their politics were read both from, and back upon, everyday objects, actions, and places: complex relations to the city were reflected in infrastructural praxis.

\section{Conclusion}

An emphasis on individual choice and responsibility obscures both the limited field of options available and the structural processes that construct such fields (Mol 2008). Beyond reinforcing a moralizing stance, the Illegal Dumping Campaign placed blame on marginalized communities for the absence of sufficient services and infrastructure, masking the structural processes producing exclusion and abjection (Rodgers, O'Neill 2012; Anand 2012). While this approach is similar to other South African public service programs that seek to teach proper neoliberal subjectivity in relation to shifting access to basic services (Miraftab 2004; von Schnitzler 2008), the approach of the municipality reproduces not only processes of abjection but, critically, also a politics of blame that serves to further remove marginalized communities from expectations of resource redistribution.

31 In every interview I asked Zanele residents how they would describe their community to someone who had never been there, people often said: «this place we live is dirty, it's not a good place». Waste was a major problem and many complained about the nyu-nyu - even those who emptied waste there. Explanations did not end there, with waste left decontextualized, but rather presented frustrations with the absence of waste receptacles, the inadequacy of sanitation provision, and the extent of community attempts to secure formal services from the city over the decades of Zanele's existence. The nyu-nyu was a painful daily symbol of risk, exclusion, and the inability to compensate for absent formal infrastructure. Against an emphasis on individual action, which works to obscure structural limitation and power, the community presented a self-aware analysis of the broader processes that forced their actions and revealed the elusive promise of post-apartheid inclusion.

Infrastructure, and the relationships surrounding it, offers a unique site for the examination of responsibility: shared structures, simultaneously material and sociopolitical, make responsibility for them difficult to identify (Star 1999; Ferguson 2012). Materially, as objects and networks located in specific places, infrastructure's sites and uses frame particular encounters with resources and practices of governance (Anand 2012; Rodgers, O'Neill 2012; Larkin 2013; Hetherington 2014). In post-apartheid South Africa this presents a potent political terrain, the site of profound social re-making 
(von Schnitzler 2016), and one in which the complexities of local experience must be read against and within municipal policies, practices, and logics.

The Illegal Dumping Campaign simplified a complex social and political problem. The basic images and equations of the campaign lurk not only entrenched social ideas about informality, but also the neoliberal ideologies that frame the struggles of peripheries as the fault of individuals and not of governance failures. Everyday actions that exist beyond the formal infrastructural grid are used by the city to mark residents as irresponsible, and to justify further distancing from service provision. The decontextualized approach to waste portrayed in the campaign - that world of floating diapers and implied actions - elides legality and responsibility, blaming residents for service absence. In the fractured city, characterized by persistent inequality (Bank 2011), the mere existence of the material landscapes of informality is increasingly used to explain why their inhabitants remain there.

\section{BIBLIOGRAPHY}

Anand N., 2012 «Municipal Disconnect: On Abject Water and its Urban Infrastructure», in Ethnography, 13(4): 487-509.

Appadurai, A. 2002 «Deep Democracy: Urban Governmentality and the Horizon of Politics», in Public culture, 14(1): 21-47.

Appadurai, A. 2004 «The Capacity to Aspire: Culture and the Terms of Recognition», in V. Rao and M. Walton (eds.), Culture and Public Action, Stanford University Press, Stanford: 59-84.

Bakker K., 2003 An uncooperative commodity: Privatizing water in England and Wales, Oxford University Press, Oxford.

Bank L., 2011 Homes Spaces, Street Styles: Contesting Power and Identity in a South African City, Pluto Press, London.

Besteman C., 2008 Transforming Cape Town, University of California Press, Berkeley.

Briggs C., 2004 Stories in the Time of Cholera: Racial Profiling During a Medical Nightmare, University of California Press, Berkeley.

Chance K., 2015 "“Where there is fire, there is politics": Ungovernability and Material Life in Urban South Africa», in Cultural Anthropology, 30(3): 394-423.

CCT (City of Cape Town), 2012 City of Cape Town 2011 Census - Cape Town, Strategic Development and GIS Department. Census data supplied by Statistics South Africa.

CCT (City of Cape Town), 2013 City of Cape Town - 2011 Census Suburb Khayelitsha, Strategic Development and GIS Department, Census data supplied by Statistics South Africa.

CCT (City of Cape Town), 2015a City awareness drive calls on communities to help stop illegal dumping. Statement by the City's Executive Mayor, Patricia de Lille, Media Release No. 40 / 2015, 22 January 2015. 
CCT (City of Cape Town), 2015b City of Cape Town @CityofCT, Twitter, January 22, 2015, https:// twitter.com/cityofct/status/558253337205039104.

CCT (City of Cape Town), 2015c City of Cape Town's Facebook Page. Post January 27, 2015.

CCT (City of Cape Town), 2020 Water and Waste: Directorate Executive Summary of the Service Delivery and Budget Implementation Plan 2020/21, City of Cape Town 2020/21 Directorate Executive Summaries and Scorecards, http://resource.capetown.gov.za/documentcentre/Documents/ City\%20strategies,\%20plans\%20and\%20frameworks/ 11_Directorate_Executive_Summary_20202021_WaterandWaste.pdf.

Cook G., 1992 « Khayelitsha: new settlement forms in the Cape Peninsula», in D.M. Smith, (ed.), The Apartheid City and Beyond: Urbanization and Social Change in South Africa, Routledge, London: 125-135.

Dawson M., 2010 «The Cost of Belonging: Exploring Class and Citizenship in Soweto's Water War», Citizenship Studies 14(4): 381-394.

Desai R., C. McFarlane, S. Graham, 2015 «The Politics of Open Defecation: Informality, Body, and Infrastructure in Mumbai», in Antipode, 47(1): 98-120.

Ferradás C.A., 2013 «The Nature of Illegality Under Neoliberalism and Post-Neoliberalism», in Political and Legal Anthropology Review, 36(2): 266-273.

Ferguson J., 2009 «The Uses of Neoliberalism», in Antipode 41(S1): 166-184.

Ferguson J., 2012 «Structures of Responsibility», in Ethnography, 13(4): 558-562.

Ferguson J., 2015 Give a Man a Fish: Reflections on the New Politics of Distribution, Duke University Press, Durham.

Ferguson J., A. Gupta, 2002 «Spatializing States: Toward an Ethnography of Neoliberal Governmentality», in American Ethnologist, 29(4): 981-1002.

Galvin M., A. Habib, 2003 «The Politics of Decentralisation and Donor Funding in South Africa's Rural Water Sector», in Journal of Southern African Studies, 29 (4): 865-884.

Graham S., S. Marvin, 2001 Splintering Urbanism: Networked Infrastructures, Technological Mobilities and the Urban Condition, Routledge, New York.

Hart G., 2008 «The Provocations of Neoliberalism: Contesting the Nation and Liberation after Apartheid», in Antipode, 40(4): 678-705.

Hart G., 2013 Rethinking the South African Crisis: Nationalism, Populism, and Hegemony, University of KwaZulu-Natal Press, Scottsdale.

Harvey E., 2005 «Managing the Poor by Remote Control: Johannesburg's Experiments with Prepaid Water Meters», in D.A. McDonald and G. Ruiters (eds.), The Age of Commodity: Water Privatization in Southern Africa, Earthscan, London: 120-127.

Hetherington K., 2014 «Waiting for the Surveyor: Development Promises and the Temporality of Infrastructure», in Journal of Latin American and Caribbean Anthropology, 19(2):195-211.

Heyman J.M., 2013 «The Study of Illegality and Legality: Which Way Forward?», in Political and Legal Anthropology Review, 36(2): 304-307.

Heyman J.M., A. Smart, 1999 «States and Illegal Practices: An Overview», in J. Heyman (ed.), States and Illegal Practices, Berg, Oxford: 1-24. 
Jaglin S., 2008 «Differentiating networked services in Cape Town: Echoes of splintering urbanism», in Geoforum, 39: 1897-1906.

James D., 2013 «Citizenship and land in South Africa: From rights to responsibilities», in Critique of Anthropology, 33(1): 26-46.

Kaika M., E. Swyngedouw, 2000 «Fetishizing the Modern City: The Phantasmagoria of Urban Technological Networks», in International Journal of Urban and Regional Research, 24 (1): 120-138.

Makhulu A., 2015 Making Freedom: Apartheid, Squatter Politics, and the Struggle for Home, Duke University Press, Durham.

Mbembe A., S. Nuttall, 2004 «Writing the World from an African Metropolis», in Public Culture, 16(3): 347-372.

McDonald D.A., G. Ruiters, 2005 «Theorizing Water Privatization in Southern Africa», in D.A. McDonald and G. Ruiters (eds.), The Age of Commodity: Water Privatization in Southern Africa, Earthscan, London: 13-42.

McFarlane C, J. Silver, 2017 «The Political City: "Seeing Sanitation" and Making the Urban Political in Cape Town», in Antipode, 49(1): 125-148.

Miraftab F., 2004 «Making Neo-liberal Governance: The Disempowering Work of Empowerment», in International Planning Studies, 9(4): 239-259.

Miraftab F., S. Wills, 2005 «Insurgency and Spaces of Active Citizenship: The Story of the Western Cape Anti-Eviction Campaign in South Africa», in Journal of Planning Education and Research, 25(2): 200-217.

Mol A., 2008 The Logic of Care: Health and the Problem of Patient Choice, Routledge, New York.

Mosse D., 2008 «Epilogue: The Cultural Politics of Water - A Comparative Perspective», in Journal of Southern African Studies, 34(4): 939-948.

Ndifuna Ukwazi, 2014 Our Struggle for Safety and Justice in Khayelitsha: The O'Regan-Pikoli Commission of Inquiry into policing in Khayelitsha, Cape Town.

Oldfield S., S. Greyling, 2015 «Waiting for the state: A Politics of Housing in South Africa», in Environment and Planning A: Economy and Space, 47: 1110-1112.

Oldfield S., K. Stokke, 2007 «Political Polemics and Local Practices of Community Organizing and Neoliberal Politics in South Africa», in H.Lettner et al (eds.), Contesting Neoliberalism: Urban Frontiers, Guildford Press, New York: 139-156.

Pieterse E., 2008 City Futures: Confronting the Crises of Urban Development, Zed Books, London.

Robins S., 2014a «Poor Wars as matter out of place: 'Toilets for Africa' in Cape Town», in Anthropology Today, 30(1): 1-3.

Robins S., 2014b «The 2011 Toilet Wars in South Africa: Justice and Transition between the Exceptional and the Everyday after Apartheid», in Development and Change, 45(3): 479-501.

Robins S., A. Cornwall, B. von Lieres, 2008 «Rethinking 'Citizenship' in the Postcolony», in Third World Quarterly, 29(6): 1069-1086.

Rodgers D., B. O’Neill, 2012 «Infrastructural violence: Introduction to the special issue», in Ethnography, 13(4): 401-412.

Ross F., 2010 Raw Life, New Hope: Decency, Housing and Everyday Life in a Post-apartheid Community, University of Cape Town Press, Cape Town. 
von Schnitzler A., 2008 «Citizenship Prepaid: Water, Calculability, and Techno-Politics in South Africa», in Journal of Southern African Studies, 34(4): 899-917.

von Schnitzler A., 2016 Democracy's Infrastructure: Techno-Politics and Protest after Apartheid. Princeton University Press, Princeton.

Simone A., 2004 «People as Infrastructure: Intersection Fragments in Johannesburg», in Public Culture, 16(3): 407-429.

SJC (Social Justice Coalition), 2013 Report of the Khayelitsha "Mshengu" Toilet Social Audit.

Star S.L., 1999 «The Ethnography of Infrastructure», in American Behavioral Scientist, 43(3): 377-391.

Storey A. 2014 «Making Experience Legible: Spaces of Participation and the Construction of Knowledge in Khayelitsha», in Politikon: South African Journal of Political Studies, 41(3): 403-420.

Thomas K., R. Galemba, 2013 «Illegal Anthropology: An Introduction», in Political and Legal Anthropology Review, 36(2): 211-214.

Thompson L., 2014 «Agency and Action: Perceptions of Governance and Service Delivery Among the Urban Poor in Cape Town», in Politikon 41(1): 39-58.

Thorn J., S. Oldfield, 2011 «A Politics of Land Occupation: State Practice and Everyday Mobilization in Zille Raine Heights, Cape Town», in Journal of Asian and African Studies 46(5): 518-530.

\section{APPENDIXES}

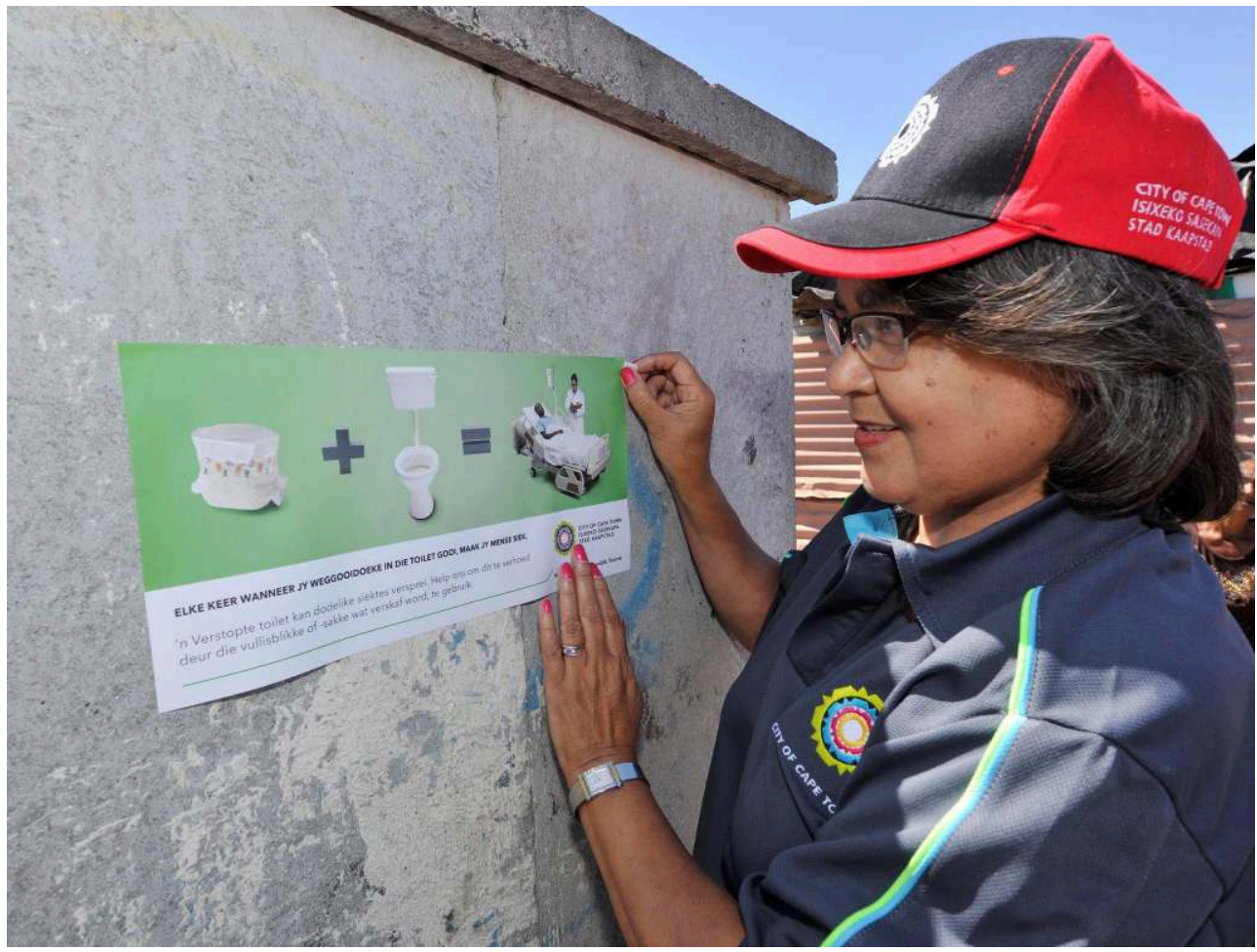

Picture 1. Cape Town's mayor at the launch of the Illegal Dumping Campaign. Image posted by the City of Cape Town to their official Twitter account on January 22, 2015. https://twitter.com/cityofct/status/558253337205039104. 


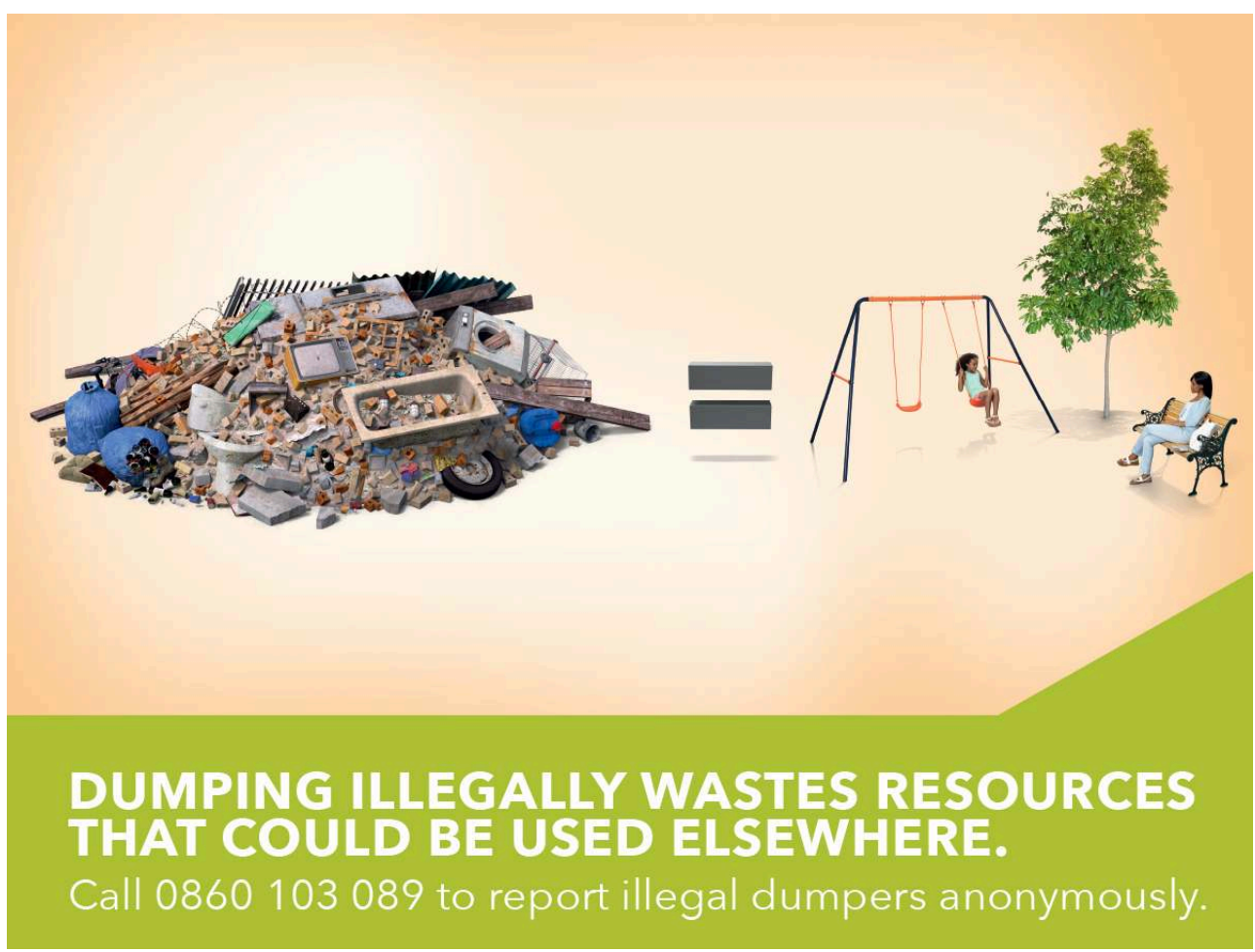

Picture 2. Poster from the Illegal Dumping Campaign. Image posted by the City of Cape Town to their official Facebook account on January 27, 2015. www.facebook.com/CityofCT/photos/a. $441013082602283.89736 .144985128871748 / 803062143064040$

\section{ENDNOTES}

1. Translated from Afrikaans: "Elke keer wanneer jy weggooidoeke in die toilet gooi, maak jy mense siek." Posters are in several languages. The three versions of the poster show a disposable diaper, a feminine hygiene pad, and a pile of rags.

2. Approximately US $\$ 30$ million at the time, based on average exchange rate for January 2015 of 11.56 ZAR to 1 USD.

3. Interviews were conducted in English and/or Xhosa, the home language of most participants, based upon their fluency and comfort. All interviews were audio recorded, and covered by Human Subjects approval at the University of Arizona (US). The data was collected solely for purposes of academic research.

4. The term isiXhosa refers to the language of the amaXhosa people; both can be shortened to Xhosa.

5. In Xhosa the sign read: "Iipesenti ezingama99.1 zabantu bethu zineetephy. Masilondoloze iinkonzo zethu, ukuze sibe nekamva elingcono".

6. Names of individual residents and informal settlements are pseudonyms.

\section{ABSTRACTS}

Nearly one quarter of Cape Town's population lives in informal settlements, sites characterized by limited access to basic infrastructure. This article examines how local experiences with waste management reinforce resident understandings of squatted sites as political and material landscapes, emphasizing the structural and spatial foundations of persistent exclusion. Such local understandings are set against the municipality's neoliberal framing of resident 
interactions with waste and infrastructure as irresponsible and illegal, implying that residents are to blame for service limitations and using this to justify further restrictions. Drawing from public service campaigns and ethnographic research, this article examines neoliberal ideologies as discourses of blame that erase the political context for marginalized lives, and argues for the need to understand ideologies of governance by setting them against the broad politics of everyday life.

Circa un quarto della popolazione di Cape Town vive in insediamenti informali, luoghi caratterizzati da un limitato accesso ai servizi di base. Questo articolo esamina come alcune esperienze locali relative alla gestione dei rifiuti rinforzino la comprensione dei residenti delle zone occupate in quanto panorami politici e materiali, enfatizzando le basi strutturali e spaziali della loro persistente esclusione. Tale comprensione locale viene mobilitata contro la municipalità, che inquadra le interazioni dei residenti con i rifiuti e con le relative infrastrutture come irresponsabili e illegali, incolpandoli così dei limiti imposti nell'erogazione dei servizi e giustificando ulteriori restrizioni. Prendendo spunto da dati etnografici e dall'analisi di diverse campagne della pubblica amministrazione, questo articolo esamina le ideologie neoliberali concretizzatesi in discorsi colpevolizzanti che cancellano la dimensione politica delle persone marginalizzate e dimostra il bisogno di comprendere tali ideologie di governance posizionandole nel quadro delle più ampie politiche della vita quotidiana.

\section{INDEX}

Keywords: waste, neoliberal governance, urban informality, infrastructure, responsibility

Parole chiave: rifiuti, governance neoliberale, infrastruttura, informalità urbana, responsabilità

\section{AUTHOR}

ANGELA D. STOREY

Department of Anthropology, University of Louisville angela.storey@louisville.edu 